\section{Determinants of Dividend Policy: A Case of Serbia's Banking Sector}

\author{
Biljana Jovković \\ University of Kragujevac, Faculty of Economics, Republic of Serbia \\ bjovkovic@kg.ac.rs
}

\section{Aleksandra S. Vasić}

University of Kragujevac, Faculty of Economics, Republic of Serbia apesterac@kg.ac.rs

\section{Jasmina Bogićević}

University of Kragujevac, Faculty of Economics, Republic of Serbia jasminab@kg.ac.rs

\begin{abstract}
Dividend policy is one of the most controversial areas of corporate finance. The paper presents the results of the research in the banking sector of the Republic of Serbia. The specific characteristics of the financial sector make the research on dividend policy determinants additionally complex. This study aims to determine the factors of dividend policy in the Serbian banking sector in the period 2009-2018. The model of random effects was chosen to test the relationship between dividend determinants and dividend payout. Empirical results show that previous years' dividends have a significant positive effect on dividend policy. Individual investors can benefit from the research to a great extent, as well as bank managers, when creating dividend policies that would contribute to maximising profit and satisfying the needs of employees and shareholders in the long run.
\end{abstract}

\section{Introduction}

Profit as the primary business motive, driving power, and breaking point of various interest groups and is at the centre of the corporate companies' functioning. On the one hand, there are corporate assets entrusted to managers for managing, while on the other hand, there are shareholders that strive to realise the income on the invested capital. The dividend represents the only regulatory channel by which it is possible to transfer corporate assets to shareholders (Malinić, 1999, 226). The set of all dividend decisions is contained in dividend policy. The policy of profit distribution is contained in the dividend policy. Dividend policy is one of the most controversial topics and researched areas of corporate finance.

The profit generated by banks is faced with the challenges of choosing the optimal dividend policy that would reconcile the views on the distribution of disposable income to the part retained for reinvestment and the part that goes to shareholders through dividends. Dividend policy in the banking sector was not so often the subject of research in academic literature, as is the case with
ORIGINAL SCIENTIFIC PAPER

RECEIVED: FEBRUARY 2021

REVISED: FEBRUARY 2021

ACCEPTED: MARCH 2021

DOI: 10.2478/ngoe-2021-0002

UDK: 336.763.2(497.11)

JEL: G21, G30

Citation: Jovković, B., Vasić S. A., \& Bogićević, J. (2021). Determinants of Dividend Policy: A Case of Serbia's Banking Sector. Naše gospodarstvo/Our Economy, 67(1), 13-22. DOI: 10.2478/ ngoe-2021-0002

\section{NG OE}

NAŠE GOSPODARSTVO OUR ECONOMY

\begin{tabular}{l|l|l} 
Vol. 67 & No. 1 & 2021 \\
\hline
\end{tabular}

pp. $13-22$ 
the companies that belong to some non-financial sectors (Baker et al., 2001; Agyei \& Marfo-Yiadom, 2011; Dibia, 2018). The reason for this is the specific financial structure, the presence of stricter and specific regulatory demands, differentiation in the field of managing, etc. (Jabbouri, 2016; Dewasiri et al., 2019).

The main goal of the paper is to investigate the determinants of dividend policy in the banking sector of the Republic of Serbia. This study considers the impact of six variables, namely, profitability, liquidity, leverage, the previous year`s dividend, bank size, and the growth rate of income on interest on the dividend payout ratios. The paper contributes to literature extension, as there are very few papers studying the dividend policies in the financial sector from developing countries. The findings are important for individual investors and bank managers when creating dividend policies that would maximise profit and satisfy employees' and shareholders' needs in the long-term period. Apart from introductory and concluding considerations, the paper is structured into three units. Within the first one, the review of theoretical and empirical literature will be presented. The development of research hypotheses, model description, and defining samples will make the content of the second unit, while the research results will be presented in the last one.

\section{Literature Review}

Many dividend theories have tried to explain how the dividend decisions are being taken, the trends in dividend movements, which factors affect them, and the connection of dividend payouts with the market value of companies. The research of Dewasiri \& Weerakoon (2016) implies that the study of dividend policy cannot rely only on one theory, but that certain explanations of this subject can be provided only along with the development of a holistic observation model. The primary starting point of the famous Miller \& Modigliani (1961) theory of irrelevancy of dividends is the presumption of perfect functioning of the capital market, perfect certainty, and rational behaviour. In their paper, the creators of this theory express the attitude according to which dividend policy in the conditions of a perfect capital market is completely irrelevant in terms of its impact on the market value of a company. The absence of dividend payouts proves that shareholders are entirely indifferent between dividends and capital gains. The critics of the Miller \& Modigliani theory (1961) imply the groundlessness of assumptions on which the expressed conclusions are based and raise the question of the validity of expressed theses in real market conditions.
In the following years, theoretical and empirical literature predominately focused on examining the dividend policy in companies in the conditions of market uncertainty. Free of the assumptions on perfect market functioning, simultaneously recognising market irregularities, Gordon (1963) and Lintner (1962) presented their literature theories popularly called Bird-in-the-hand Theory. Starting from the assumption that there is a natural aversion to risk, Gordon (1963) emphasises that the investors (shareholders) prefer relatively certain dividends concerning uncertain capital gains. In the real and imperfect world, investors do not have the same information at their disposal that is available to managers in terms of business risk and business in general. Further theoretical research was aimed at the possibility that the investors are sent certain messages (signals) by the market by carrying out a specific dividend policy. The theory of dividend signals connects dividend policy with informational asymmetry (Shchurina \& Prunenko, 2018, 992). It starts from the assumption that the dividend payout ratio signals information to investors about the future performance of firms (Al-Kayed, 2017, 119). The growth of dividends directs investors to the conclusion that the management of the company believes that its position is better than the current prices reflect, and that it is realistic to expect that the growth of share prices will follow the growth of dividends.

Significant efforts in academic circles to solve the controversy of dividend policy have resulted in plenty of research in the past few decades. The first in line, Lintner (1956), tried to obtain the answers to the questions related to dividend policy through the research of American companies that belong to the industrial sector. He concluded that the decisions on dividend payouts are based on the current profitability and last year's dividends, which follows the relevance of dividend policy on the value market of companies. After expressing opposite attitudes by Miller \& Modigliani (1961) in the theory of irrelevance, a high number of researchers followed in this field. Since the theory of irrelevance was based on the hypotheses that are not characteristic of real business conditions, the critics (Gordon, 1963; Lintner, 1962; Litzenberger \& Ramaswamy, 1979) started from modified hypotheses. On the basis of observation of American companies that are listed on the New York stock exchange market, Baker \& Powell (1999) came to the findings that dividend payouts are following theories - Bird-in-the-hand and dividend signals. The justification for the theory of dividend signals is offered by the research results of Arko et al. (2014). Their work is based on consistent evidence that the decisions on dividends are affected by the level of profitability, taxes, investment opportunities, leverage, and risk. In the paper of Yarram \& Dollery (2015), the hypothesis on signalisation of dividend payouts 
was confirmed on the example of Australian companies. The results show that the companies that pay out dividends are bigger on average, more profitable, and more influential, with a lower rate of growth and risk compared to the companies that do not prefer dividend payouts.

In an effort to answer the question about what factors affect dividend policy, a comprehensive piece of research by Jabbouri (2016) that encompassed a ten-year observation of 533 companies listed in the stock markets of Middle Eastern countries was carried out. Banks and financial companies were excluded from the analysis due to their specific financial structure, accounting methods, and corporate management. A positive relation of dividend policy with company size, profitability, and liquidity was spotted, while the growth rate, leverage, and economic development expressed a negative connection with dividend policy. According to what was said, the paper of Dewasiri et al. (2019) confirmed the relation of profitability and growth rate with the policy of dividend payouts. Apart from the mentioned determinants, based on the data of 191 companies that were observed in the period from 2010 to 2016, the authors emphasise that dividend policy is also affected by the previous year's dividends, investment opportunities, corporate management, ownership, and the branch of industry which the company belongs to. Starting from different economic development in which companies operate and comparing dividend policies of the companies of developing countries with the companies in the USA, Aivazian et al. (2003) concluded that national factors affect both the structure of dividend policy and its sensitivity to the effect of different determinants. However, besides the differences, in principle, there is an agreement regarding the effect of profitability and leverage on dividend policy.

Dividend policy is in economic theory most often studied from the aspect of companies that belong to some of the non-financial sectors. As the main reasons for excluding banks and other financial companies from empirical research, Dewasiri et al. (2019) stated high leverage was present at those companies, as well as specific regulatory demands related to their business. Dividend payouts of banks depend greatly on strictly prescribed regulations in this sector, which makes the research of the factors that affect dividend policy become a more complex challenge in relation to the same problems of companies from the industrial sector. Baker et al. (2001) noticed the differentiation in dividend policy attitudes between the managers of financial and non-financial sectors. The results have shown a statistically significant difference in 9 out of 22 separate factors in total, whereby the most important are earning stability, the level of current income, and expected income. Larger dividend payouts weaken financial power and the ability of banks to take on more risk (Basse et al., 2014, $6)$. This is the main reason why the increase of dividends in the banking sector is not always interpreted as a positive signal to investors.

Specific characteristics of the financial sector have affected the decreased scope of empirical research on key determinants of dividend policy in this field. Analysing financial companies in Ghana, Agyei \& Marfo-Yiadom (2011) concluded that profitability, leverage, previous year's dividends, growth, and risk are the main factors that show a statistically significant impact on dividend policy. According to the above, Zameer et al. (2013) revealed a positive connection of profitability and previous year's dividends with dividend policy on the example of the banking sector in Pakistan, which is in the context of the theory of dividend signals. Apart from the aforementioned, the research singled out liquidity and ownership structure as equally influential factors. Dibia (2018) establishes that dividend policy in Nigeria's banking sector is subjected to the impact of profitability, total assets at the disposal of a bank, and the amount of leverage, while the variable of previous dividend payouts has not shown satisfying statistical significance. In a ten-year observation (2005-2015) of banks listed on the Dakar stock market, Hosain (2016) singles out liquidity and leverage as the most important determinants of dividend policy. On the other hand, with determinants like risk, ownership structure, and the amount of total assets at the disposal of a bank, the direct impact has not been noticed. Unlike the previously mentioned research, Basse et al. (2014) discarded the findings of the theory of dividend signals by observing the European banking sector in the period of the financial crisis. This paper has not supported the attitudes according to which dividend reductions are a reliable sign of future problems for investors and financial analysts. On the contrary, it is considered that European banks should turn their policy to the model of dividend reduction to strengthen their financial position in the period of facing a financial crisis.

\section{Methodology of Research}

\section{The development of research hypotheses}

In the literature review, the key explanations and relations of certain factors to dividend policy were emphasized. The purpose of the research is to establish the critical determinants of dividend policy on the example of banks that operate in the territory of the Republic of Serbia. Banks are the cornerstone of a country's financial system, especially in the emerging market economies where capital markets are 
underdeveloped (Zhang, Jiang, Qu, \& Wang, 2013). The specificity of the financial sector of the Republic of Serbia is reflected in the dominant presence of banks, which makes the area of dividend policy research in this sector attractive. In this paper, dividend policy, as a dependent variable, is observed via dividend payout ratio, defined as the ratio between total dividends and net profit. Potential variables whose impact on dividend policy is examined are profitability, liquidity, leverage, previous year's dividend, bank size, and growth rate of income on interest.

The decision on dividend payout in companies starts with the realised profit; hence it is not surprising that profitability is considered one of the most critical variables of dividend policy. In his paper, Dibia (2018) finds a positive connection between profitability and dividends. Zameer et al. (2013) emphasise that highly profitable companies distribute a larger share of their profit through dividends. Starting from previous research, the profitability of banks will be measured with the ROA variable (Return on assets). According to everything mentioned previously, the following hypothesis is formed:

H1: Profitability has a statistically significant positive impact on dividend policy.

Liquidity is considered one of the most critical factors of dividend policy. And, while a strand of literature ( $\neg$ Jabbouri, 2016; Hosain, 2016) relates high liquidity to a better financial position that provides the possibility of more significant dividend payouts, others (Banerjee et al., 2005; Dewasiri et al., 2019) find a negative relation between these two variables. Most often, this type of connection is present in the banking sector. Zameer et al. (2013) consider that banks have more significant needs for liquidity compared to the non-financial sector. And, when they mark high liquidity, banks strive to maintain the current level to respond to all challenges readily. Following the research of Marfo-Yiadom \& Agyei (2011), liquidity is expressed as the relation between cash and net assets of a bank. According to the aforementioned, we start from the following hypothesis:

\section{H2: Liquidity has a statistically significant negative impact on dividend policy.}

The level of indebtedness is one more variable that is related to dividend policy. Increased exposure of a company to risks leads to higher levels of leverage. High indebtedness decreases the possibility of sending dividend signals to investors (Jabbouri, 2016, pp. 292). Al-Kayed (2017) emphasises that banks with a high level of leverage are subjected to stricter regulations, which is negatively reflected on dividend payout. As in Hosain's (2016) paper, we express leverage by putting into relation total liability with the total assets of banks. The hypothesis we started from is the following:

H3: Leverage has a statistically significant negative impact on dividend policy.

A high growth rate of income on interest represents the signal to investors that a company is in the phase of open investment opportunities, whereby each new investment decreases the amount that remains for the dividend payout. Dewasiri et al. (2019) emphasised that the growth observed through the availability of investments represents an essential determinant of dividend payout. Al-Kayed (2017) finds negative relation between these two variables. The growth rate will be followed through the growth of income on interest, as in the paper of Marfo-Yiadom \& Agyei (2011). According to the arguments presented, the following hypothesis is formed:

H4: Growth rate has a statistically significant negative impact on dividend policy.

Lintner (1956) singled out previous dividends as one of the determinants of dividend policy. The results of Dickens et al. (2002) emphasise dividends from previous years as the critical factor in determining dividend policy in the banking sector. The amount of last-year dividend payouts defined in a national currency as an absolute number is used for expressing the variable of previous dividends. Based on the research of Al-Kayed (2017) and Dewasiri et al. (2019), the following hypothesis is formed:

\section{H5: Previous year's dividends have a statistically signifi- cant positive impact on dividend policy.}

Investors estimate larger companies as less risky, with a better financial market position, easier approach to assets, and larger dividend payouts. Bank size was singled out as an important factor in determining dividend policy in the research of $\neg \neg$ Jabbouri (2016). The papers of Dickens et al. (2002) and Dibia (2018) also confirm the positive connection of these two variables. For the research of bank size, following the research of Hosain (2016), the natural logarithm of total assets will be used. Based on the aforementioned, we started from the following hypothesis:

H6: Bank size has a statistically significant positive impact on dividend policy. 


\section{Empirical model and data}

Empirical research is based on the analysis of the panel data series, as the combination of cross-section data and time series (Dragutinovic Mitrovic, 2002, 12). The research focuses on the banking sector of the Republic of Serbia, with 27 banks operating in 2018 (National Bank of Serbia, 2018). Out of the total number, the basis of this research consists of ten banks chosen according to the criteria of total assets at the end of 2018 (Graph 1). Given that the market share of those ten banks was $78.1 \%$ at the time, the authors considered it a sufficient choice for the sample. The variables examined in the paper consist of secondary data collected from annual reports of the chosen banks, published decisions on the use and distribution of profit, and the reports published by the National Bank of Serbia. The time span of the research is ten years, from 2009 to 2018.

Figure 1. Total Asset Value (in 1,000s RSD)



Source of data: National Bank of Serbia, 2018.

The application of panel regression requests the choice between the model of fixed effects and the model of random effects. For that purpose, the Hausman test is used in the paper. The Zero hypothesis of this test implies the acceptance of a random effects model, in contrast to the alternative hypothesis that speaks in favour of the fixed effects model (Hosain, 2016, 8). If it is supposed that there is no correlation between a random error and independent variables, the random effects model is more adequate, while otherwise, it is considered that in the assessment of parameters, it is better to use a fixed effect model (Dibia, 2018, 6). In Table 1, the results of the Hausman test were shown. The amount of 7.84 Chi-Square with the probability of 0.2500 implies that the model of random effects is more adequate in the analysis of collected data.

Table 1. Hausman Test

\begin{tabular}{l|l|l}
\hline Test summary & Chi. Sq. Stat & $\boldsymbol{p}$-value \\
\hline & 7.840421 & 0.2500 \\
\hline
\end{tabular}

Unlike the model of fixed effects, random effect model assumes that there is no individual specific effect of companies. However, all factors that affect the dependant variable are unified and contained in random error term. Simply put, the factors that can manifest their impact on a dependent variable, and are not contained in some of the independent variables, are approximately presented by the value of random error. The model of random effects can be presented in the following way:

$Y_{\text {it }}=\beta_{0}+\beta_{1} X_{1 \text { it }}+\beta_{2} X_{2}$ it $+\beta_{3} X_{3 \text { it }}+\beta_{4} X_{4 \text { it }}+\beta_{5} X_{5 \text { it }}+$ $\beta_{6} \mathrm{X}_{6 \text { it }}+\beta_{\mathrm{i}}+\beta_{\mathrm{it}}$

whereby $\mathrm{Y}$ represents the dependent variable (dividend payout ratio), $\mathrm{X}_{1}, \mathrm{X}_{2}, \mathrm{X}_{3}, \mathrm{X}_{4}, \mathrm{X}_{5}$, and $\mathrm{X}_{6}$ are independent variables (profitability, liquidity, leverage, growth rate of income on interest, previous year's dividends, and bank size). The error term is $\varepsilon_{\mathrm{i}}+\varepsilon_{\mathrm{it}}$ and the regression parameter is $\beta$. The model is restricts the co-efficient of the explanatory variables to be common across the units (i) and the time period $(t)$. Unlike the basic model, the component of random error $\varepsilon_{i}$, which is specific for individual observation units, is added to random error $\varepsilon_{\text {it }}$, referring to the combination of time series and comparative data.

Table 2 gives a summed review of previously presented variables used in this research.

Table 2. Variables, description and expectation

\begin{tabular}{|c|c|c|c|}
\hline Variables & Symbol & Description & Expectation \\
\hline \multicolumn{4}{|c|}{ Depended Variable } \\
\hline $\begin{array}{l}\text { Dividend } \\
\text { payout ratio }\end{array}$ & DPR & $\begin{array}{l}\text { Cash dividend / } \\
\text { Net profit }\end{array}$ & \\
\hline \multicolumn{4}{|c|}{ Independed Variable } \\
\hline Profitability & PROF & $\begin{array}{l}\text { Return on Asset } \\
\text { (ROA) }\end{array}$ & + \\
\hline Liquidity & LIQ & $\begin{array}{l}\text { Cash and cash } \\
\text { equivalent / } \\
\text { Net asset }\end{array}$ & - \\
\hline Leverage & LEV & $\begin{array}{l}\text { Total liability / } \\
\text { Total asset }\end{array}$ & - \\
\hline Growth rate & GR_R & $\begin{array}{l}\text { (Current interest } \\
\text { income - Last year } \\
\text { interest income) / } \\
\text { Last year interest } \\
\text { income }\end{array}$ & + \\
\hline $\begin{array}{l}\text { Previous } \\
\text { year's } \\
\text { dividends }\end{array}$ & PREV_DIV & $\begin{array}{l}\text { Last year } \\
\text { dividend }\end{array}$ & + \\
\hline Bank size & BSZ & $\begin{array}{c}\text { Natural logarithm } \\
\text { of total asset }\end{array}$ & + \\
\hline
\end{tabular}


Testing the set of research hypotheses was carried out with the help of corresponding statistical methods and with the support of the statistical package EViews.

\section{Results and Discussion}

The collected data will be processed and analysed in four stages. Firstly, the research started from the presentation of dividend policy that chosen banks with headquarters in the Republic of Serbia had pursued in the last ten years. After that, a statistical description of the observed variables in the sample will follow. Then, by applying correlation and regression analysis, the relation and impact of dependent variables on independent ones will be examined within the third and fourth stages.
The overview of dividend policy through the amounts of paid out dividends represents often used and at the same time the simplest form of observing. Table 3 presents the amounts of paid out dividends in the last ten years on the example of the ten biggest banks in the Republic of Serbia.

There are three banks singled out in the table above, which in the observed time interval did not pay out dividends Erste bank, Eurobank, and OTP Group. The losses from previous years, retained earnings in the company, growth, and development financing are just some of the reasons for the absence of dividend distribution to their shareholders. The continuity in dividend payouts for the observed period was noticed only with Kombank. AIK and Raiffeisen bank are following. Table 3 shows that good results of the first six largest banks for the last two years (2017 and 2018) provided the opportunity of consecutive payout of dividends to

Table 3. Dividend Payout (in 1,000s RSD)

\begin{tabular}{l|c|c|c|c|c|c|c|c|c|c}
\hline & Intesa & Unicredit & Kombank & Societe & Raiffeisen & AIK & Erste & Eurobank & Postanska & OTP \\
\hline $\mathbf{2 0 0 9}$ & 0 & 0 & 44,820 & 0 & 0 & 455,208 & 0 & 0 & 1,967 & 0 \\
\hline $\mathbf{2 0 1 0}$ & 0 & 0 & 44,822 & 0 & 0 & 756,762 & 0 & 0 & 1,967 & 0 \\
\hline $\mathbf{2 0 1 1}$ & 0 & 0 & 37,575 & 0 & 0 & 149,917 & 0 & 0 & 1,967 & 0 \\
\hline $\mathbf{2 0 1 2}$ & 0 & $1,135,000$ & 40,264 & 0 & $4,936,731$ & 200,000 & 0 & 0 & 7,598 & 0 \\
\hline $\mathbf{2 0 1 3}$ & 0 & 0 & 37,351 & 0 & $4,657,614$ & 210,000 & 0 & 0 & 0 & 0 \\
\hline $\mathbf{2 0 1 4}$ & 0 & 0 & 604,620 & 0 & $5,616,555$ & 0 & 0 & 0 & 0 & 0 \\
\hline $\mathbf{2 0 1 5}$ & 0 & $2,500,000$ & $1,962,751$ & 0 & $5,227,634$ & $3,120,182$ & 0 & 0 & 224,211 & 0 \\
\hline $\mathbf{2 0 1 6}$ & 0 & $2,600,000$ & 23,531 & 0 & $4,341,952$ & $3,377,934$ & 0 & 0 & 0 & 0 \\
\hline $\mathbf{2 0 1 7}$ & $18,110,986$ & $1,250,000$ & 16,808 & $5,748,046$ & $5,411,291$ & $3,743,569$ & 0 & 0 & 0 & 0 \\
\hline 2018 & $20,034,339$ & $1,255,000$ & $2,535,916$ & $4,864,010$ & $6,626,785$ & $10,049,237$ & 0 & 0 & 110,100 & 0 \\
\hline
\end{tabular}

Source of data: National Bank of Serbia, 2018.

Table 4. Descriptive statistics

\begin{tabular}{l|c|c|c|c|c|c|c}
\hline & $\begin{array}{l}\text { Dividend } \\
\text { payout ratio }\end{array}$ & Profitability & Liquidity & Leverage & Growth rate & $\begin{array}{c}\text { Previous } \\
\text { year`s } \\
\text { dividends }\end{array}$ & $\begin{array}{c}\text { Bank size } \\
\text { Mean }\end{array}$ \\
\hline Median & 0.1779 & 0.0117 & 0.6909 & 0.5179 & 0.0509 & 0.1225 & 18.9634 \\
\hline Maximum & 1.7808 & 0.0577 & 4.2227 & 0.9119 & 1.8136 & 1.5286 & 20.1683 \\
\hline Minimum & -0.3116 & -0.1462 & 0.0693 & -8.1391 & -0.2875 & -0.3116 & 17.2772 \\
\hline $\begin{array}{l}\text { Standard } \\
\text { deviation }\end{array}$ & 0.3901 & 0.0241 & 0.5320 & 1.3126 & 0.2336 & 0.3105 & 0.7094 \\
\hline Skewness & 2.3197 & -3.6911 & 3.3311 & -5.3774 & 4.7886 & 2.5813 & -0.6790 \\
\hline Kurtosis & 7.8302 & 22.1889 & 21.2285 & 32.533 & 34.8241 & 9.0822 & 2.9304 \\
\hline
\end{tabular}


the shareholders. The most significant benefit in the given period was realised by the shareholders of the bank Intesa, whose payouts exceeded the amount of RSD 38 billion in total. At the same time, this represents the most significant amount that any of the observed banks paid out in the tenyear period that was analysed in the paper.

The amounts of paid out dividends in previous years are used to calculate the rate of dividend payout, a dependent variable that serves as a representative of dividend policy in this research. Table 4 shows the descriptive statistics for each of the variables whose impact on dividend policy is being examined along with the dependent one.

By the analysis of arithmetic mean value, standard deviation, asymmetry, and flattening are interpreted as sample characteristics. The average amount of earnings paid out in the form of dividends is $17.79 \%$ (Mean $=0.1779$ ). The average rate of income to assets is $1.17 \%$, while the average growth rate is about 5\%. The biggest standard deviation from arithmetic mean value is marked with variable Leverage (Std. Dev. = 1.3126). The most significant standard deviation from the arithmetic mean value is marked with variable Leverage $($ Std. Dev. $=1.3126)$. The obtained values of distribution asymmetry show both positive and negative asymmetry in relation to the mean value. All flattening results are positive, which implies that the distribution is more peaked than a normal one.

The analysis of the strength and direction of observed variables is performed with the help of correlation analysis. For determining statistical importance, the significance level $\alpha=0.05$ was used. The value of the correlation coefficient up to 0.3 implies weak correlation; from 0.3 to 0.5 the mean value, while the values above 0.5 imply a strong correlation connection between variables (Pallant, 2017, 134). The direction of correlation implies positive or negative signs of the correlation coefficient. A positive value implies that with the growth of one variable the grows other as well, and vice versa. On the other hand, negative values represent an inverse movement of variables, with the growth of one comes the reduction of the other, and vice versa. In Table 5, the correlation matrix of all examined variables is given.

The correlation analysis results showed a statistically important correlation between certain pairs of variables with the probability of $95 \%$ and $99 \%$. Specifically, in this research, the greatest importance will be to examine the correlation between dividend policy and independent variables. The strongest, statistically significant relation is noticed between the growth of dividend payout ratio and previous year`s dividends $(\rho=0.663$; $p=0.000)$. In the case of a somewhat weaker relation and the probability of $99 \%$, the positive relation between dividend payout ratio and bank size was observed $(\rho=0.291 ; p=0.003)$. Apart from the aforementioned, the rate of dividend payout is correlated with the profitability of banks as well $(\rho=0.222$; $p=0.027$ ). By observing pairs of independent variables, the mean correlation relation was observed between profitability and bank size $(\rho=0.431 ; p=0.000)$. Also, analysis results imply weak, positive relation of bank size and previous year`s dividends ( $\rho=0.233$; $p=0.019$ ), as well as between bank size and leverage $(\rho=0.209$; $p=0.037)$.

Table 5. Correlation matrix

\begin{tabular}{l|c|c|c|c|c|c|c}
\hline & $\begin{array}{c}\text { Dividend } \\
\text { payout ratio }\end{array}$ & Leverage & Liquidity & $\begin{array}{c}\text { Previous } \\
\text { year’s } \\
\text { dividends }\end{array}$ & Profitability & Growth rate & Bank size \\
\hline $\begin{array}{l}\text { Dividend } \\
\text { payout ratio }\end{array}$ & 1 & & & & & & \\
\hline Leverage & 0.0895 & 1 & & & & & \\
\hline Liquidity & 0.0397 & -0.0103 & 1 & & & & \\
\hline $\begin{array}{l}\text { Previous } \\
\text { year's divi- } \\
\text { dends }\end{array}$ & $0.6635^{* *}$ & 0.0793 & 0.1049 & & & & \\
\hline Profitability & $0.2218^{*}$ & -0.0147 & -0.0371 & 0.1603 & & & \\
\hline Growth rate & -0.1225 & 0.1547 & 0.0750 & -0.1343 & -0.0061 & & 1 \\
\hline Bank size & $0.2906^{* *}$ & $0.2089^{*}$ & 0.0763 & $0.2332^{*}$ & $0.4311^{* *}$ & -0.0675 & 1 \\
\hline
\end{tabular}

The results significant at $5 \%$ significance level are followed by ${ }^{*}$ and at $1 \%$ significance level by ${ }^{* *}$. 
A regression analysis was applied to determine the association between the explanatory and dependent variables. The testing of the research hypothesis has been done with the help of the random effects model. The obtained results are presented in the Table 6:

The value of determination coefficient $\mathrm{R}^{2}$ is 0.466 , which means that $46 \%$ of the variability of dividend policy is explained by the regression model, while the rest of the variability is under the impact of other factors. The Adjusted R square is 0.431 . The F statistic value is 13.525 (p-value = 0.000 ), which at the significance level of $5 \%$, implies that the hypothesis of the existence of significant linear relation between dependent and independent variables is accepted. The values of the Durbin-Watson test of 2.153 imply that there is no autocorrelation.

By observing the values ( $\beta$ coefficient, $t$ value, and $p$ statistical significance) given in Table 6 on independent variable Profitability, a positive ( $\beta=1.176)$, but not a statistically significant impact on the dependent variable can be established ( $p=0.396)$. On that basis, the hypothesis $\mathrm{H} 1$ is rejected. The obtained results are consistent with the re- search of Puspitaningtyas (2019). As expected, Liquidity shows negative, but like in the previous explanation, it is about the value that has no statistically significant impact on dividend payout. The hypothesis $\mathrm{H} 2$ is also easily rejected. Leverage and growth rate of income on interest do not show a statistically significant impact on the dependent variable; thus, it comes to the rejection of hypotheses H3 and H4. Zameer et al. (2013) came to similar results in their research when it comes to these two independent variables. Unlike the previously mentioned ones, the variable Previous year's dividends confirms the correctness of the hypothesis $\mathrm{H} 5$, according to which last-year dividend payouts have a statistically significant $(p=0.000)$, positive $(\beta=0.784)$ impact on dividend policy. The results speak in favour of using the previous year's dividends as the type of signal of what potential investors can expect in the future. The value of $p=0.000$ implies a highly statistically significant relation, which is confirmed in numerous works of research (Hosain, 2016; Al-Kayed, 2017; Dewasiri et al., 2019). When it comes to the last examined determinant, the value of $\beta=0.061$ and $p=0.210$ do not show a statistically significant impact of bank size on dividend policy, by which the hypothesis $\mathrm{H} 6$ is rejected.

Table 6. Regression results

\begin{tabular}{l|c|c|c|c}
\hline Depended Variable & Independed Variable & $\beta$ & $\boldsymbol{t}$-value & Sig. \\
\hline Dividend payout ratio & Profitability & 1.1762 & 0.8519 & 0.3965 \\
\hline & Liquidity & -0.0216 & -0.3828 & 0.7027 \\
\hline & Leverage & 0.0039 & 0.1694 & 0.8658 \\
\hline & Growth rate & -0.0439 & -0.3391 & 0.7353 \\
\hline & Previous year`s dividends & 0.7844 & 7.8784 & $0.0000^{* *}$ \\
\hline & Bank size & 0.0612 & 1.2628 & 0.2098 \\
\hline
\end{tabular}

R square $(R 2)=0.4660 ; F=13.5246(p(F$ statistic $)=0.000)$; Durbin-Watson stat. $=2.153$

Significance: ${ }^{*} p \leqslant 0.05 ;{ }^{* *} p \leqslant 0.01$ 


\section{Conclusion}

As the material basis in which the interest of various groups of corporate companies is being diffracted, the profit has been the subject of studies in economic theories for decades. Researchers' special attention is attracted by dividend policy, especially the one implemented by the companies that belong to the finance sector. This research focuses on determining dividend policy factors of the banking sector in the Republic of Serbia by applying the regression model of random effects. By a choice of six determinants (profitability, liquidity, leverage, growth rate of income on interest, previous year's dividends, and bank size) whose impact on dividend policy was examined in the paper, we concluded that only one of them could explain the movements of dividend payouts. Previous year's dividends have shown as the most significant variable in predicting future dividend payouts. The positive impact of the last-year dividends offers support in defining dividend policy that should rely on previous payout patterns. A statistically significant impact of profitability, leverage, dividend payout rate, and bank size on dividend policy has not been found in the paper.
Deficiencies/limitations of the research. Research limitation refers to the size of the sample. In the observed period, a significant number of observation units were noticed that did not contain dividend payout; hence the recommendation is to expand spatial and time observation of variables to decrease mistakes and increase the correctness of findings.

Practical implications and the directions of future research. Individual investors can benefit from the research to a great extent when choosing the banks whose shares they invest in. If an investor prefers companies that pay out dividends, the first indicator that they observe on that occasion is dividend payouts in previous years. Research results can also help bank management make efficient and reliable decisions on dividend payouts that, in the longterm period, could contribute to maximising profit and satisfying the needs of employees and shareholders. When it comes to future research directions, they should be directed to the inclusion of additional variables into the model, such as ownership, risk, economic conditions, life cycle, investment opportunities, etc. Apart from this, the recommendation for future research refers to the observation of determinants of dividend policy in other finance companies, such as insurance companies.

\section{References}

Agyei, S. K., \& Marfo-Yiadom, E. (2011). Dividend Policy and Bank Performance in Ghana. International Journal of Economics and Finance, 3(4), 202-207. doi: 10.5539/ijef.v3n4p202

Aivazian, V., Booth, L., \& Cleary, S. (2003). Do Emerging Market Firms Follow Different Dividend Policies From U.S. Firms? Journal of Financial Research, 26(3), 371-387. doi: 10.1111/1475-6803.00064

Al-Kayed, L. T. (2017). Dividend payout policy of Islamic vs conventional banks: case of Saudi Arabia. International Journal of Islamic and Middle Eastern Finance and Management, 10(1), 117-128. doi: 10.1108/imefm-09-2015-0102

Arko, C. A., Abor, J., K.D. Adjasi, C., \& Amidu, M. (2014). What influence dividend decisions of firms in Sub-Saharan African? Journal of Accounting in Emerging Economies, 4(1), 57-78. doi: 10.1108/jaee-12-2011-0053

Baker, H., \& Powell, G. H. (1999). Dividend policy issues in regulated and unregulated firms: a managerial perspective. Managerial Finance, 25(6), 1-20. doi: 10.1108/03074359910765975

Baker, H. K., Veit, E. T., \& Powell, G. E. (2001). Factors Influencing Dividend Policy Decisions of Nasdaq Firms. The Financial Review, 36(3), 19-38. doi: 10.1111/j.1540-6288.2001.tb00018.x

Banerjee, S., Gatchev, V. A., \& Spindt, P. A. (2005). Stock Market Liquidity and Firm Dividend Policy. SSRN Electronic Journal. doi: 10.2139/ssrn.391663

Basse, T., Reddemann, S., Riegler, J.J., \& von der Schulenburg, J.-M. G. (2014). Bank dividend policy and the global financial crisis: Empirical evidence from Europe. European Journal of Political Economy, 34, 25-31. doi: 10.1016/j.ejpoleco.2013.09.001

Dewasiri, N. J., \& Weerakoon Banda.Y.K. (2016). Why Do Companies Pay Dividends? A Comment. Journal of Corporate Ownership and Control, 13(2), 443-453. doi: 10.2139/ssrn.2699666

Dewasiri, N.J., Yatiwelle Koralalage, W. B., Abdul Azeez, A., Jayarathne, P. G. S. A., Kuruppuarachchi, D., \& Weerasinghe, V.A. (2019). Determinants of dividend policy: evidence from an emerging and developing market. Managerial Finance, 45(3), 413-429. doi: 10.1108/mf-09-2017-0331

Dibia, O. N. (2018). Determinants of Dividend Policy in Nigerian Banks. Archives of Current Research International, 15(2), 1-13. doi: 10.9734/ACRI/2018/44463

Dickens, R., Casey, K. \& Newman, J. (2002). Bank Dividend Policy: Explanatory Factors. Quarterly Journal of Business and Economics, 41(1), 3-12. doi: 10.2307/40473341

Dragutinović Mitrović, R. (2002). Analiza panel serija. Beograd: Zadužbina Andrejević. 
Gordon, M.J. (1963). Optimal investment and financing policy. The Journal of Finance, 18(2), 264-272. doi:10.1111/j.1540-6261.1963. tb00722.x

Hosain, Z. (2016). Determinants of the Dividend Payout Policy: A Study on Listed Private Commercial Banks of Dhaka Stock Exchange Limited in Bangladesh. IOSR Journal of Economics and Finance, 7(5), 1-10. doi: 10.9790/5933-0705040110

Jabbouri, I. (2016). Determinants of corporate dividend policy in emerging markets: Evidence from MENA stock markets. Research in International Business and Finance, 37, 283-298. doi: 10.1016/j.ribaf.2016.01.018

Lintner, J. (1956) Distribution of Incomes of Corporations among Dividends, Retained Earnings, and Taxes. The American Economic Review, 2, 97-113.

Lintner, J. (1962). Dividends, Earnings, Leverage, Stock Prices and the Supply of Capital to Corporations. The Review of Economics and Statistics, 44(3), 243-269. doi: 10.2307/1926397

Litzenberger, R. H., \& Ramaswamy, K. (1979). The effect of personal taxes and dividends on capital asset prices. Journal of Financial Economics, 7(2), 163-195. doi: 10.1016/0304-405x(79)90012-6

Malinić, D. (1999). Politika dobiti korporativnih preduzeća. Beograd: Ekonomski fakultet Univerziteta u Beogradu.

Marfo-Yiadom, E. \& Agyei, S. (2011). Determinants of dividend policy of banks in Ghana. International Research Journal of Finance and Economics, 61, 99-108.

Miller, M.H. \& Modigliani, F. (1961). Dividend Policy, Growth, and the Valuation of Shares. The Journal of Business, 34, 411-433. doi: $10.1086 / 294442$

National Bank of Serbia, Price and Financial System Stability. (2018). Annual report on activities and results in 2018.

Puspitaningtyas, Z. (2019). Assesment of financial performance and the effect on dividend policy of the banking companies listed on the Indonesia stock exchange. Banks and Bank systems, 14(1), 24-39. doi: 10.21511/bbs.14(2).2019.03

Pallant, J. (2017). SPSS priručnik za preživljavanje. Beograd: Mikro knjiga.

Shchurina, S.V. \& Prunenko, M.A. (2018). The Dividend Policy for Banking Sector: Examples Of Russian And Chinese Banks. In: Selection and peer-review under responsibility of the Organizing Committee of the conference. Paper presented at the Proceedings of the International Scientific Conference Global Challenges and Prospects of the Modern Economic Development, 990-1000. doi: 10.15405/epsbs.2019.03.99

Yarram, S. R., \& Dollery, B. (2015). Corporate governance and financial policies. Managerial Finance, 41(3), 267-285. doi: 10.1108/ mf-03-2014-0086

Zameer, H., Rasool, S., Iqbal, S. \& Arshad, U. (2013). Determinants of dividend policy: A case of banking sector in Pakistan. Middle East Journal of Scientific Research, 18, 410-424. doi: 10.5829/idosi.mejsr.2013.18.3.12200

Zhang, J., Jiang, C., Qu, B., \& Wang, P. (2013). Market concentration, risk-taking, and bank performance: Evidence from emerging economies. International Review of Financial Analysis, 30, 149-157. doi: 10.1016/j.irfa.2013.07.016

\section{Dejavniki dividendne politike: primer bančnega sektorja v Srbiji}

\section{Izvleček}

Dividendna politika je eno najbolj kontroverznih področij podjetniških financ. Prispevek predstavlja rezultate raziskave bančnega sektorja Republike Srbije. Zaradi specifičnih značilnosti finančnega sektorja je raziskovanje dejavnikov dividendne politike še bolj kompleksno. Cilj te študije je določiti dejavnike dividendne politike v srbskem bančnem sektorju za obdobje 2009-2018. Da bi preverili razmerje med dejavniki in izplačilom dividend, smo izbrali model slučajnih učinkov. Empirični rezultati so pokazali, da imajo dividende preteklih let občuten pozitiven učinek na dividendno politiko. Pričujoča raziskava bi lahko zelo koristila posameznim investitorjem in direktorjem bank pri oblikovanju dividendnih politik, ki bi pripomogle k ustvarjanju čim večjega dobička in zadovoljevanju potreb zaposlenih ter delničarjev na dolgi rok.

Ključne besede: podjetniške finance, bančni sektor, dividendna politika, determinante dividendne politike, Srbija 